\section{Influence of mother plant and scarification agents on seed germination rate and vigor in Retama sphaerocarpa L. (Boissier)}

\author{
André Fabião, Carla Faria, Maria Helena Almeida, António Fabião
}

The aim of this study was to optimize nursery production of Retama sphaerocarpa (Fabaceae), an important shrub species characterized by a seed coat dormancy hindering germination, and used in the restoration of degraded arid and semi-arid areas. To assess the influence of scarification agents and mother plant effect on germination rate and seedling vigor, a germination test with fresh seed was performed in a germination chamber using a factorial design with two fixed factors (mother plant effect and scarification agent). Fresh seeds were scarified by sulphuric acid ( $96 \%$ concentration, $60 \mathrm{~min}$ ) and hot water $\left(80{ }^{\circ} \mathrm{C}, 30 \mathrm{sec}\right)$ and their germination compared with untreated control seeds. Scarification of seeds using sulphuric acid has proven the best method to enhance germination of this species, achieving the highest germination rate (>79\%) and the best vigor index. Differences between seed lots from different mother plants were statistically significant and could influence seed germination success. We suggest that effectiveness of hot water scarification method may be improved by additional time of seed immersion. Owing to its potential for use in land restoration, bioenergy production and ornamental purposes, increment of commercial demand of this species is expected in the near future.

Keywords: Fresh Seed, Germination, Mother Plant, Retama sphaerocarpa, Scarification, Vigor

\section{Introduction}

Arid and semi-arid zones are very susceptible to anthropogenic disturbance and degradation (MacDonald \& Larsen 2009, Vallejo 2009). Usually plant cover is scarce in these areas, being susceptible to disturbance 2009). Also, human activities often impoverish natural seed banks, negatively influencing the regeneration capacity of arid and semi-arid ecosystems (Bonet 2004, Cortina et al. 2004). Therefore, natural regeneration of Mediterranean woodlands after disturbance is often absent or very slow (Thirgood 1981, Vallejo 2009). Consequently, the area occupied by such ecosystems has decreased considerably over the centuries, particularly in the driest areas (e.g. Silva 1969, Thirgood 1981, Blondel \& Aronson 1999, Radich \& and prolonged drought periods (Vallejo
Alves 2000). The effects of non-sustainable land management practices, such as intensification of grazing, could limit successional patterns and vegetation responses to natural disturbance (Lafortezza et al. 2013). Nitrogen cycling may be a key factor in those processes, as well as the occurrence of ruderal plants with phytotoxic capabilities that inhibit other plant species. The establishment of a nitrogen-fixing plant prone to play a facilitation role in disturbed woodlands, like Retama sphaerocarpa (L.) Boissier, may represent an opportunity to rehabilitate degraded communities (Rivest et al. 2011).

Suitable management and restoration activities in Mediterranean woodlands are fundamental, in that vegetation cover may mitigate erosion and desertification effects, preserving soil quality and favoring soil evolu- $\square$ Centro de Estudos Florestais, Instituto Superior de Agronomia, Universidade de Lisboa, Tapada da Ajuda, P-1349-017 Lisboa (Portugal)

@ André Fabião (andrefabiao@isa.ulisboa.pt)

Received: Oct 18, 2013 - Accepted: Jan 20, 2014

Citation: Fabião A, Faria C, Almeida MH, Fabião A, 2014. Influence of mother plant and scarification agents on seed germination rate and vigor in Retama sphaerocarpa $\mathrm{L}$. (Boissier). iForest 7: 306-312 [online 2014-04-08] URL: http://www.sisef.it/iforest/ contents/?id=ifor1155-007

Communicated by: Gianfranco Minotta tion (Castillo et al. 1997, Piotto \& Di Noi 2003). Such activities imply the diversification of plant species used in restoration projects, a broad use of the wide variety of native species available, and the consideration of wildlife, microorganisms, soil and flora as an integrated framework (Vallejo 2009).

Retama sphaerocarpa (Fabaceae family) is a shrub naturally growing in the above mentioned ecosystems of northern Africa and the Iberian peninsula. It is a common species in Portugal, mainly in the southern part of the country, although its natural distribution includes much of central Portugal and some areas in the interior north deep valleys (Bingre et al. 2007). This species is well adapted to the seasonal water stress conditions and shallow soils typical of semi-arid Mediterranean ecosystems, showing morphological and architectural features suitable to water conservation, such as small leaf area (very small leafs, only present for a short period during the spring) and the presence of photosynthetic stems with a vertical orientation that minimize light interception and overheating (Haase et al. 1996). Additionally, it has a thick root system, which can reach 25 meters deep through crevices in the soil parent material (Haase et al. 1996). It also has the ability to hydraulically lift water from deep to shallow soil layers (Prieto et al. 2010).

$R$. sphaerocarpa exhibits a broad ecological range with no specific soil type preference, although it suffers much hardship in very cold or humid locations. It can be found in the Iberian Peninsula from sea level up to 1400 meters of elevation (Ruiz de la Torre et al. 1996, Talavera 1997, Lopez Gonzalez 2004).

As many other woody species typical of the Mediterranean region and other semi-arid zones, Retama sphaerocarpa grows for a short period of time in the spring, with favorable temperature and soil moisture conditions (Haase et al. 2000). Fruit production is often abundant, normally occurring between the end of July and the beginning of August. The seeds have a hard seed coat, measuring approximately $3.5-5 \times 5-8 \mathrm{~mm}$ (Talavera 1997) and weighting between 90 and $100 \mathrm{mg}$ (Pugnaire et al. 2006). The main seed dispersal agent is the wind, although water and sometimes animals are also involved in the dispersal process (Haase et al. 2000, Manzano et al. 2005, Pugnaire et al. 2006).

Retama sphaerocarpa plays an important role in the restoration of degraded areas, due to its capability to withstand dry environments, the symbiosis between its root system and nitrogen-fixing bacteria, its phytoremediation capabilities, and also its importance in some plant communities of arid and semiarid zones (Benayas et al. 2002, Caravaca et al. 2003, Moreno-Jiménez et al. 2011). 
Moreover, it has some potential as a cultivated crop for energy production, for carbon sequestration and for ornamental purposes in Mediterranean gardens (Ruiz de la Torre et al. 1996, Barceló \& Parera 2005, Ruiz-Peinado et al. 2013).

Similar to many Mediterranean shrub species (Piotto \& Di Noi 2003), information on Retama sphaerocarpa propagation in the literature is scarce and often inaccurate, likely due to the physical dormancy of its seeds that hinders the germination process (Pugnaire et al. 2006). Under natural conditions dormancy allows the persistence of viable seeds within the soil seed bank over long time periods (Willan 1991). Seed hardiness gradually declines over time as a result of natural factors, which may include the friction with soil particles (mechanical scarification), wildfire heat (thermal scarification), or the action of digestive acids when seeds are eaten by wildlife and/or domestic animals (chemical scarification - Willan 1991, Hartmann et al. 1997, Robles et al. 2005, Gibson et al. 2011). The persistence on the soil seed bank allows the survival of some viable seeds until the occurrence of environmental conditions favorable to germination, plant survival and growth (Willan 1991, López et al. 1999, Pugnaire \& Lázaro 2000).

Several pre-germination treatments may be used in the nursery to emulate the mentioned natural processes, such as the immersion in near-boiling water or sulphuric acid, the physical abrasion or pressure, or the seed exposure to low or alternating temperatures (Hartmann et al. 1997). López et al. (1999) reports germination rates after 30 days of 40$47 \%$ (after a pre-germination treatment of 1 minute in $100{ }^{\circ} \mathrm{C}$ water, simulating natural warming due to wildfires), $97-100 \%$ (following 60 minutes in sulphuric acid, $96 \%$ concentration, simulating animal consumption) and $0 \%$ (untreated seed). These values refer to seed collected in the same year and stored in paper bags at room temperature. On the other hand, Ruiz de la Torre et al. (1996) indicates germination rates of $75-85 \%$ (30 seconds in $80{ }^{\circ} \mathrm{C}$ water, followed by cooling in cold water) and of $35 \%$ (untreated seed), not mentioning the duration of the germination tests. Pérez-Fernández \& RodríguezEcheverría (2003) report germination percentages after 35 days of $5 \%$ (seeds presoaked in boiling water, followed by cooling for 8 hours) and $20 \%$ (after similar pre-soaking followed by $10 \mathrm{~min}$ of smoke exposure to simulate the chemical action of wildfire smoke).

The aim of this study was to investigate the germination performance of Retama sphaerocarpa seeds from a Portuguese provenance, with the objective of improving nursery production techniques and better understanding its seed germination characteristics, as well as its suitability for the ecological restoration of Mediterranean ecosystems and its exploitability as a bioenergy crop.

\section{Materials and methods}

\section{Seed collection and handling}

Seeds were hand-harvested at the end of September 2010 from 9 different mother plants at least 20 meters apart located in the 100-ha university campus (Fig. 1) of the Institute of Agricultural Sciences at Tapada da Ajuda (Lisbon, Portugal - 38 42' 27.61" N,

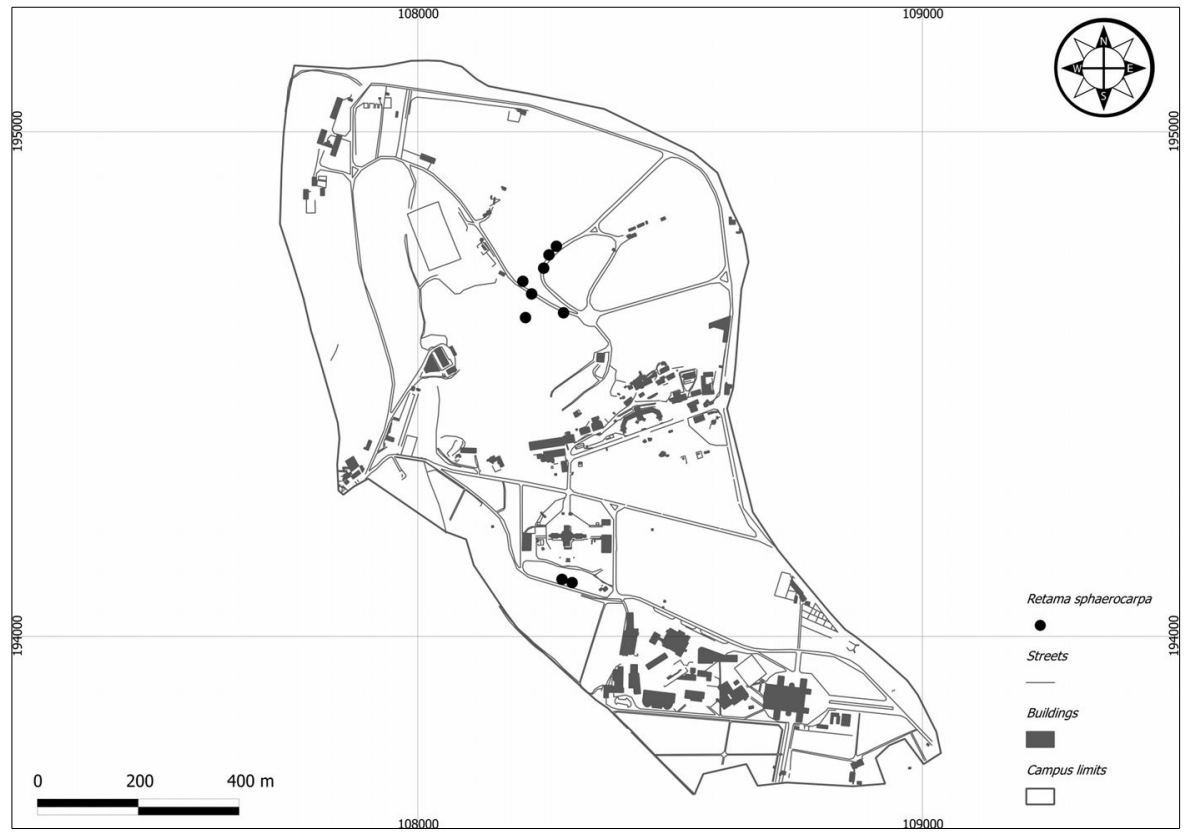

Fig. 1 - Map of the Tapada da Ajuda University Campus (Lisbon, Portugal). Black dots represent the mother plants of Retama sphaerocarpa sampled for seed germination analysis. $9^{\circ} 10^{\prime} 56.32^{\prime \prime} \mathrm{W}$, max elevation: $131 \mathrm{~m}$ a.s.1.). The sampled mother plants belong to a natural population located in Tapada da Ajuda and in the adjacent Monsanto peri-urban county forest.

Collected seeds were kept in their pods to avoid external contamination and stored in kraft paper envelopes at room temperature until the start of the trial. All damaged or unripen seeds were rejected upon shelling.

\section{Experimental design}

The germination trials started in the beginning of October 2010. Seeds were disinfected by immersion in a $1 \%$ sodium hypochlorite solution for 10 minutes and thoroughly rinsed with distilled water (Robles et al. 2005).

A factorial design with two fixed factors (mother plant effect and scarification agent) was used. Nine levels were considered for mother plant effect, and the following three levels for the scarification procedure: (A) control with no scarification agent; (B) scarification by soaking the seeds in a water solution containing $96 \%$ sulphuric acid for 60 minutes in the dark (López et al. 1999); (C) scarification by soaking the seeds in hot water $\left(80^{\circ} \mathrm{C}\right)$ for 30 seconds, followed by cooling down at room temperature in distilled water (Ruiz de la Torre et al. 1996). A total of 27 different treatments ( 9 mother trees x 3 scarification procedures) were considered. Each treatment had 3 replications per mother plant (3 samples with 20 seeds each), totaling 60 seeds per each mother plant and treatment. Overall, a total of 1620 seeds were used.

No specific ISTA (International Seed Testing Association) rules do exist for Retama sphaerocarpa, so ISTA rules for Cytisus spp. were used as for substrate, temperature and trial duration (ISTA 2003). However, ISTA recommendations on the mechanical scarification of seeds for breaking dormancy in the latter species were not applied, due to the small size of Retama sphaerocarpa seeds and the time consumption of their scarification without suitable devices.

The germination test was carried out in modified Jacobsen's individual apparatus trays (Willan 1991) placed into a germination chamber at a temperature of $21 \pm 3{ }^{\circ} \mathrm{C}$, with no moisture control and in the dark. Seed watering was carried out whenever needed (every 2-3 days, on average) by placing the seeds on a filter paper moistened with distilled water.

\section{Data analysis}

Seeds showing an emerging radicle $\geq 1 \mathrm{~mm}$ were considered as germinated, then counted and removed from the trays (López et al. 1999). Seeds showing fungal contamination on the whole coat surface were removed and considered as non-germinated. 
Tab. 1 - Classes of the germination vigor index $(V)$, as proposed by López et al. (1999).

\begin{tabular}{lc}
\hline Category & Value range \\
\hline Very fast & $33.33 \leq V \leq 100$ \\
Fast & $11.11 \leq V<33.33$ \\
Average & $5.0 \leq V<11.11$ \\
Slow & $0.0<V<5.0$ \\
Null & $V=0.0$ \\
\hline
\end{tabular}

The number of germinated seeds for each treatment was recorded, and the corresponding germination percentages obtained. Germination vigor index $(V)$ was calculated for each treatment as a measure of the germination rate per unit time, following the method proposed by López et al. (1999):

$$
V=(a / 1+b / 2+c / 3+d / 4+\ldots+x / n) \cdot \frac{100}{S}
$$

where $a, b, c, \ldots$ represents the number of germinated seeds after $1,2,3, \ldots$ days, respectively; $x$ is the number of seeds germinated at the end of the trial ( $n$-th day); and $S$ is the total number of seeds in the survey. The index values range between 0 and 100 (null to very fast), and were categorized as reported in Tab. 1 (López et al. 1999).

\section{Statistical analysis}

All statistical analyses were carried out by the use of the SPSS $^{\circledR}$ software package (PASW Statistics, v. 18.0.0, 2009).

Departure of the germination data from normal distribution was tested by applying the D'Agostino-Pearson's test (D'Agostino et al. 1990), using a SPSS-macro developed by DeCarlo (1997). Given the assumptions for the analysis of variance were not met after data transformation, suitable non-parametric tests were used.

To ascertain for differences in germination and germination vigor index among scarification procedures, a Kruskal-Wallis test was carried out. Significance of pairwise differences between treatments was assessed by Games-Howell's multiple comparisons test using mean ranks (Ruxton \& Beauchamp 2008). Finally, Mann-Whitney U-test was used to assess the statistical significance of differences in the germination and germination vigor index among mother plants.

\section{Results}

\section{Scarification effect on germination and} vigor

After 28 days of survey, seeds scarified with sulphuric acid (treatment B) showed the best results, with a germination percentage of $79.4 \pm 3.8 \%$ (mean \pm standard error over the 9 mother plants). Germination success for seeds scarified with hot water (treatment C) was only $28.7 \pm 3.8 \%$. Control treatment showed the lowest germination percentage

Tab. 2 - Mean \pm standard error of germination percentages and germination vigor index for seeds subjected to three treatments after 28 days of survey. Different letters indicate significant pairwise differences between treatments after Games-Howell's test $(\mathrm{p}<0.05)$.

\begin{tabular}{lccc}
\hline Treatment & Number of seeds & $\begin{array}{c}\text { Germination } \\
\text { percentage }\end{array}$ & $\begin{array}{c}\text { Germination } \\
\text { vigor index }\end{array}$ \\
\hline (A) Control & 540 & $11.3 \pm 1.8^{\mathrm{a}}$ & $3.85 \pm 0.75^{\mathrm{a}}$ \\
(B) Sulphuric Acid & 540 & $79.4 \pm 3.8^{\mathrm{b}}$ & $39.13 \pm 2.47^{\mathrm{b}}$ \\
(C) Hot water & 540 & $28.7 \pm 3.8^{\mathrm{c}}$ & $9.00 \pm 1.41^{\mathrm{c}}$ \\
\hline
\end{tabular}

(only $11.3 \pm 1.8 \%$ ). According to vigor index categories reported in Tab. 1, germination was classified as "very fast" for treatment B, "average" for treatment $\mathrm{C}$ and "slow" for treatment A. Tab. 2 displays the mean values of germination percentages and germination vigor index obtained for each treatment. The cumulative germination curves pooled over all mother plants are dis-

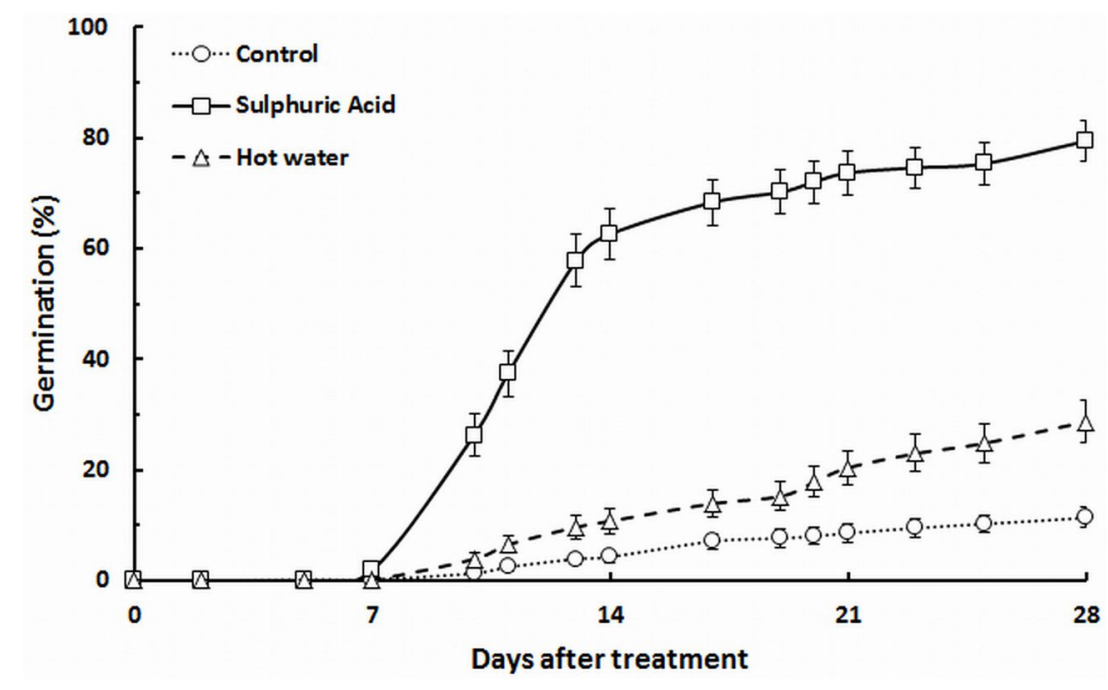

Fig. 2 - Cumulative distribution of the germination percentage in each treatment for Retama sphaerocarpa seeds. Vertical bars are standard errors $(\mathrm{n}=27)$.
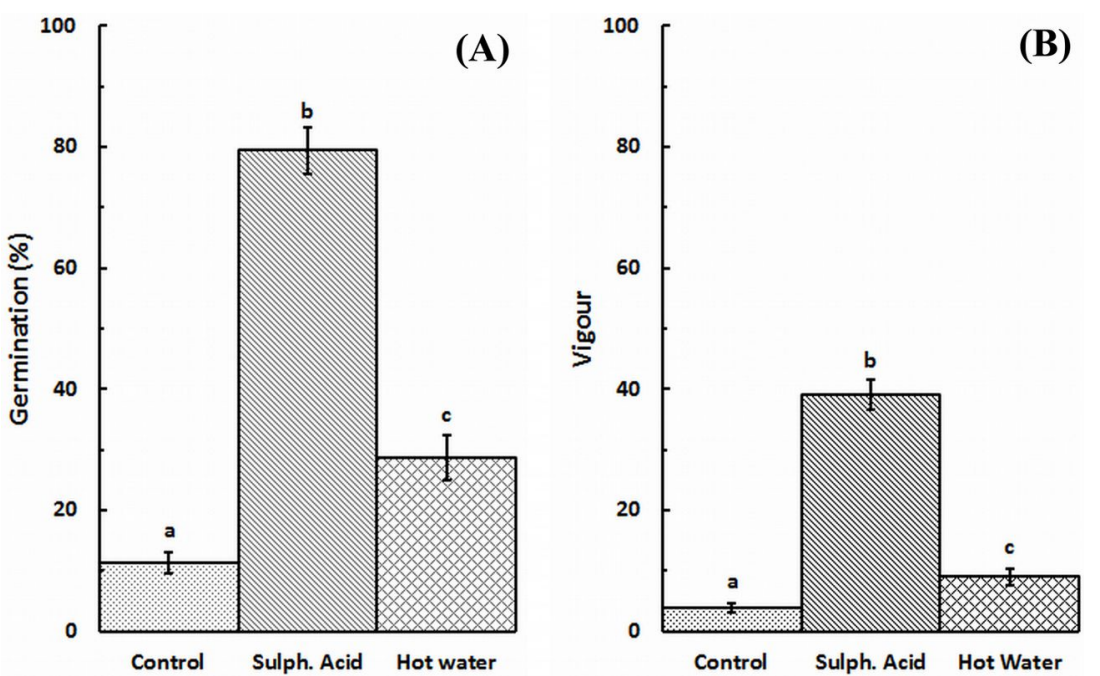

Fig. 3 - Germination rate (A) and germination vigor index (B) by treatment. Vertical bars are standard errors $(\mathrm{n}=27)$. Different letters indicate significant pairwise differences between treatments after Games-Howell's test $(\mathrm{p}<0.05)$. 
Tab. 3 - Mean \pm standard error of germination percentages and germination vigor index for seeds collected from 9 mother plants after 28 days of survey. Different letters indicate significant pairwise differences between mother plants after Mann-Whitney U-test $(p<0.05)$.

\begin{tabular}{cccc}
\hline $\begin{array}{c}\text { Mother } \\
\text { plant }\end{array}$ & $\begin{array}{c}\text { Number } \\
\text { of seeds }\end{array}$ & $\begin{array}{c}\text { Germination } \\
\text { percentage }\end{array}$ & $\begin{array}{c}\text { Germination } \\
\text { vigor index }\end{array}$ \\
\hline I1 & 180 & $18.3 \pm 6.0^{\mathrm{a}}$ & $5.95 \pm 2.22^{\mathrm{a}}$ \\
I2 & 180 & $48.4 \pm 9.6^{\mathrm{b}}$ & $24.50 \pm 5.91^{\mathrm{b}}$ \\
I3 & 180 & $47.2 \pm 9.6^{\mathrm{b}}$ & $20.09 \pm 5.06^{\mathrm{b}}$ \\
I4 & 180 & $40.6 \pm 12^{\mathrm{ab}}$ & $17.37 \pm 6.09^{\mathrm{ab}}$ \\
I5 & 180 & $42.9 \pm 9.8^{\mathrm{ab}}$ & $20.05 \pm 6.28^{\mathrm{ab}}$ \\
I6 & 180 & $40.0 \pm 11.6^{\mathrm{ab}}$ & $16.82 \pm 5.80^{\mathrm{ab}}$ \\
I7 & 180 & $52.2 \pm 9.8^{\mathrm{b}}$ & $17.53 \pm 5.20^{\mathrm{b}}$ \\
I8 & 180 & $34.4 \pm 15.2^{\mathrm{ab}}$ & $17.26 \pm 8.31^{\mathrm{ab}}$ \\
I9 & 180 & $34.4 \pm 15.2^{\mathrm{ab}}$ & $16.40 \pm 7.76^{\mathrm{ab}}$ \\
\hline
\end{tabular}
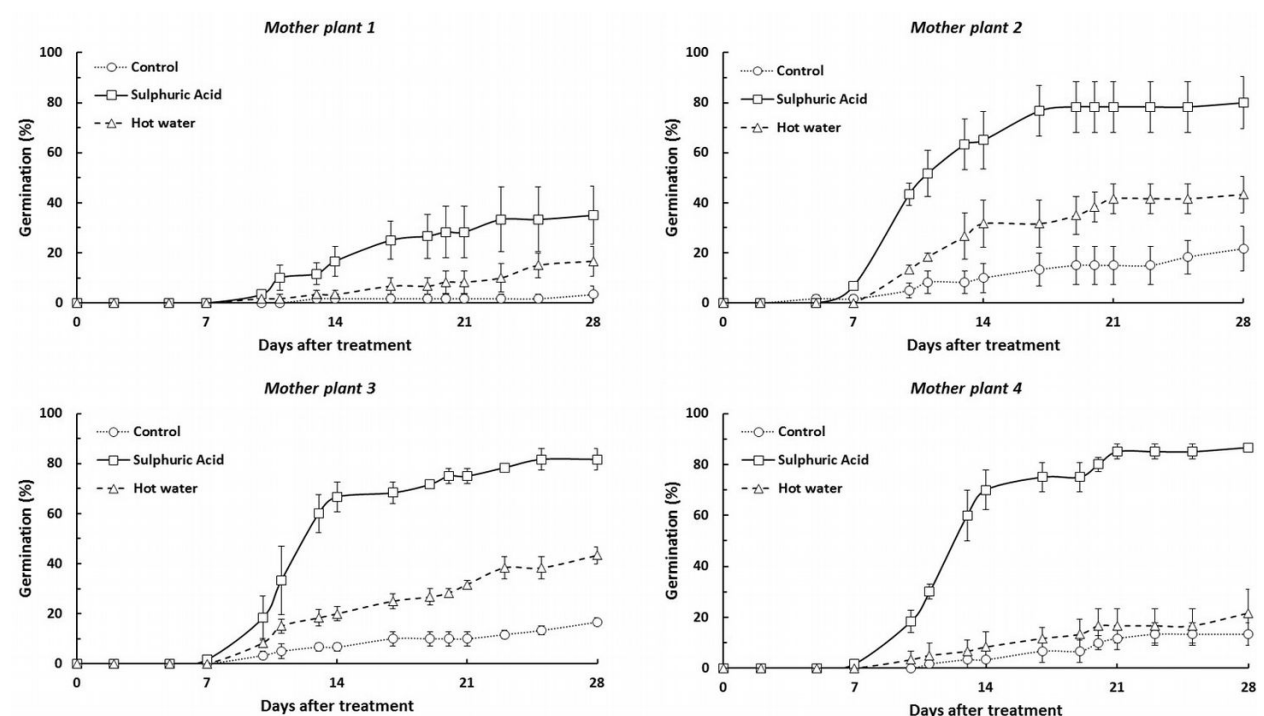

Mother plant 5

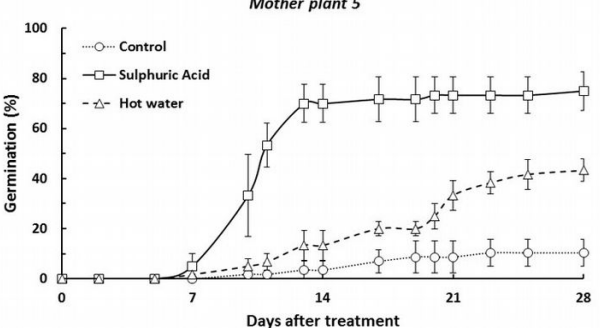

Mother plant 7
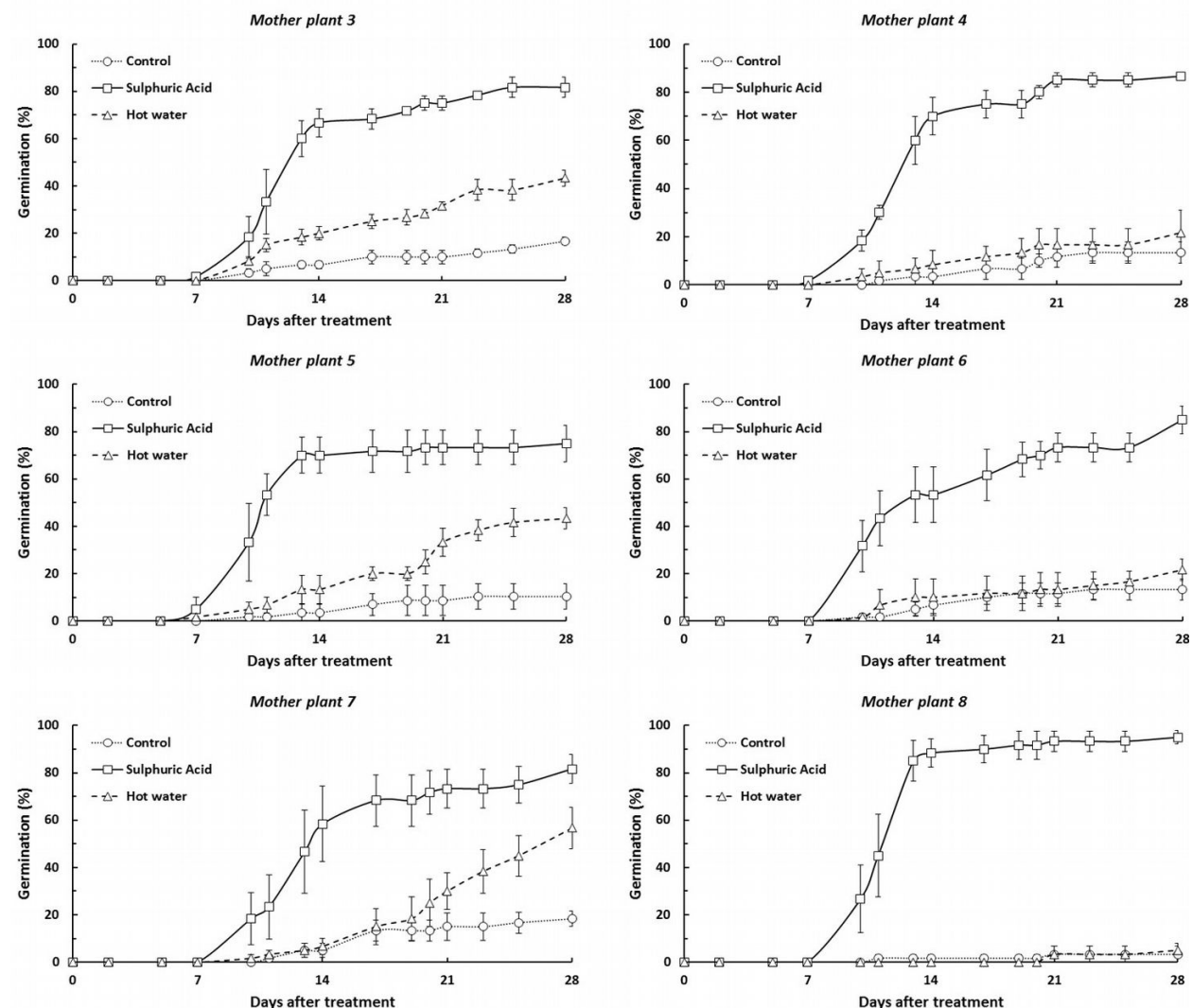

Mother plant 6

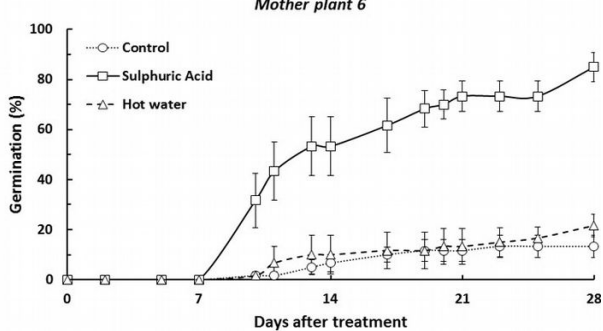

Mother plant 8

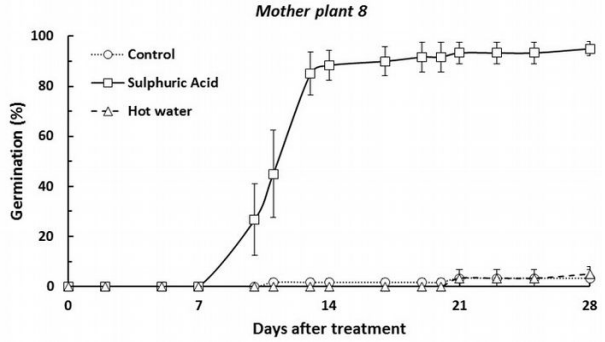

Mother plant 9

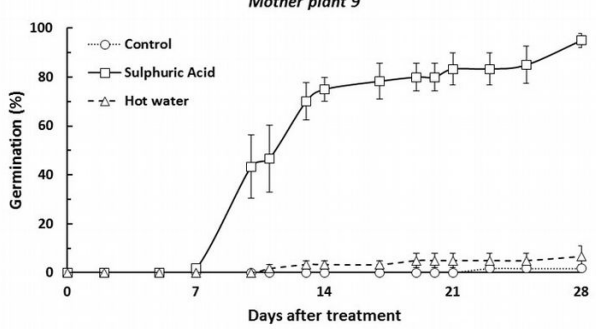

Mother plant effect on germination and vigor

Germination percentages were broadly similar among seed lots from all mother plants, with the exception of mother plant I1 and, to a lesser extent, mother plants I8 and 19. The highest germination percentage pooled over the 3 treatments was obtained for the seed lot from mother plant I7 (52.2 \pm 9.8 $\%$ ) and the lowest from mother plant I1 $(18.3 \pm 6.0 \%)$. According to vigor index categories reported in Tab. 1, germination was classified as "fast" for all seed lots, except for those from mother plant I1 which was considered as "average". Tab. 3 displays the

Fig. 4 - Germination curves of Retama sphaerocarpa by seed lots from different mother plants. Vertical bars are standard errors $(n=3)$. 
germination percentage and germination vigor index of the different mother plants. The cumulative germination curves pooled over all treatments are displayed by mother plant in Fig. 4.

Significant differences in germination rate were found between three pairs of mother plants after Mann-Whitney U-test: I1 and I2 $(\mathrm{U}=13, \mathrm{p}<0.05), \mathrm{I} 1$ and $\mathrm{I} 3(\mathrm{U}=15.5, \mathrm{p}<0.05)$ and between I1 and $\mathrm{I} 7(\mathrm{U}=14, \mathrm{p}<0.05-$ Fig. $5)$.

Germination vigor index was significantly different only between two pairs of mother trees: I1 and $\mathrm{I} 2(\mathrm{U}=12.5, \mathrm{p}<0.05), \mathrm{I} 1$ and $\mathrm{I} 3$ $(\mathrm{U}=16, \mathrm{p}<0.05$ - Fig. 5).

\section{Discussion}

Our results clearly indicate that seed scarification is needed to improve Retama sphaerocarpa germination rate for commercial seedling production in nursery. Treatmen with sulphuric acid provided the best germination results, probably due to its effectiveness in degrading the seed coat. Thermal scarification using hot water gave worse results, though in some cases its efficacy in breaking seed dormancy seems to be delayed in time (e.g., mother plant I7). As suggested by Pérez-Fernández et al. (2000) for other Fabaceae species, stronger hot water scarification (e.g., longer seed immersion) may boost the seed germination rate also for $R e$ tama sphaerocarpa.

Similar results were obtained when the germination vigor index is considered, being the seeds treated with sulphuric acid classified in the "very fast" germination category. As reported by López et al. (1999), seed scarification is needed not only to improve the germination capability, but also to speed up that process.

In this study, significant differences in germination rate and vigor were found among seed lots from different mother plants (I1 vs I2, I3 and I7). Such differences may be interpreted as of genetic origin (for example, variation of seed coat thickness among seed lots from different mother plants), or may be related with the vitality of the mother plants which may influence seed maturation (for example, different exposure to light of mother plants related with their location within the sampled area). Additional source of variation in seed germination rate may be related to the age of the collected pods. In fact, Retama shpaerocarpa shrubs tend to keep some seed pods for more than one year (Haase et al. 2000), making such seeds more prone to fungal contamination, thus reducing their germination capacity. Indeed, some fungal contamination of seeds was observed all over the germination survey carried out The most susceptible treatment to fungal infection was the thermal scarification with hot water (data not shown), but also seed lots from single mother plants (namely 1 and 5)
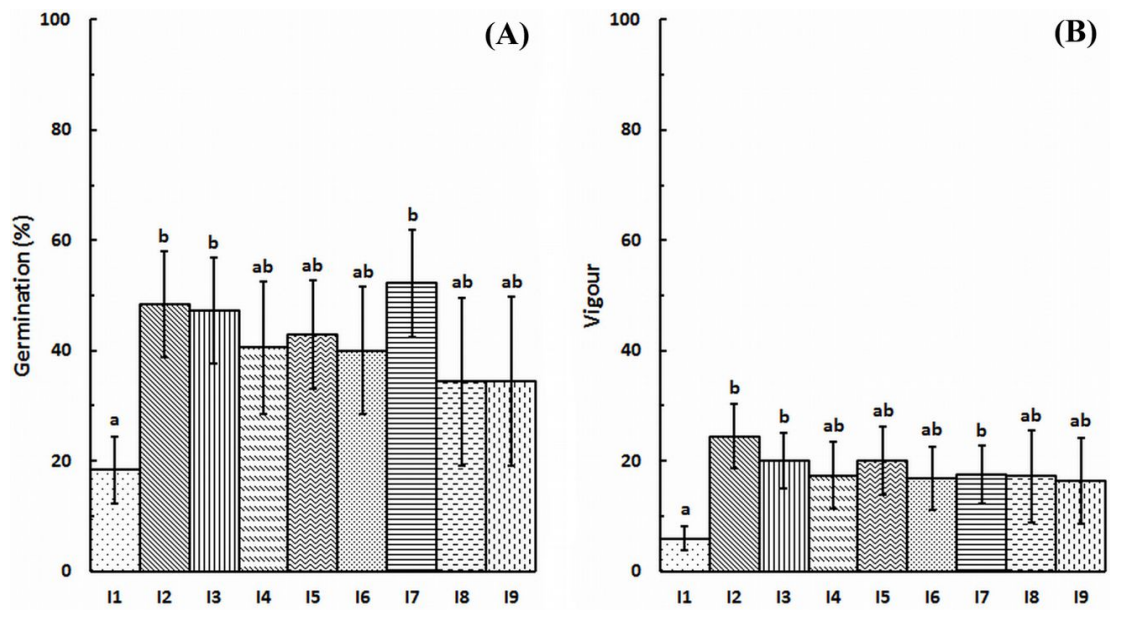

Fig. 5 - Germination rate (A) and germination vigor index (B) by mother plant. Vertical bars are standard errors $(n=9)$. Different letters indicate significant pairwise differences between mother plants after Mann-Whitney U-test $(\mathrm{p}<0.05)$.

were clearly more affected than others by contamination. Such susceptibility to infection could have possibly generated further variation in our dataset, so results (especially differences in germination among seed lots from different mother plants) should be interpreted with caution.

Seed coat thickness in legumes may considerably vary (Piotto \& Ciccarese 1999). As a consequence, the treatments applied in this study might provoke an unwanted selection, destroying seeds with lighter coats and simultaneously not scarifying seeds with thicker coats (Piotto \& Ciccarese 1999). It has been reported mechanical scarification as a safer and less damaging alternative to chemical or thermal treatments (Piotto \& Ciccarese 1999). Moreover, the use of percussion to break seed physical dormancy has been proposed as a further alternative, as successfully tested on several herbaceous Fabaceae by Mondoni et al. (2013). However, mechanical scarification of large amounts of seed (as in commercial seedling production in nursery) requires specific, highly expensive machinery. On the other hand, handling of sulphuric acid or large amounts of boiling water requires special safety measures and skilled workers.

Our results are slightly different from those reported in the literature: only the treatment with sulphuric acid obtained germination percentages in line with expectations $(79.4 \pm$ $3.8 \%$ ). However, several authors do not mention the duration of their experiments or the length of seed storage (e.g., Ruiz de la Torre et al. 1996, Pérez-Fernández \& Rodríguez-Echeverría 2003), making difficult the comparison. Several reasons could be invoked to explain the differences mentioned above: (i) the presence in the collected material of seeds at different stages of maturity; (ii) differences in the germination capacity among seed lots from different mother plants; (iii) differences in seed morphology (seed coat thickness); and (iv) differences in fungal contamination of the seed lots.

Retama sphaerocarpa has a great potential for use in restoration of degraded ecosystems and production of biomass for energy purposes, as well as for low-maintenance Mediterranean gardens. Thus, future demand for this species is expected to increase, justifying its production by commercial plant nurseries.

\section{Conclusions}

Seed scarification using 96\% sulphuric acid for 60 minutes in the dark has proven the most effective pre-germination treatment for breaking dormancy of Retama sphaerocarpa seeds, enabling the maximization of the number of germinated seeds and ensuring shorter germination times. This allows a greater age uniformity of the plant batch, which eases the management and disposal of the nursery stocks.

Pre-germination treatments with hot water may provide similar results in the future, but additional tests are recommended using longer soaking times and/or keeping the seeds immersed while the water cools down, with the main advantage of cheaper costs and safer procedures in the nursery.

Mechanical scarification might be a safer and less damaging alternative to the above treatments, although requiring suitable (and costly) machinery for handling large quantities of seed.

Genetic or vigor-related characteristics of the mother plants of Retama sphaerocarpa may influence the effectiveness of pre-germination treatments. Finally, more information is needed on the germination capacity of stored seed, and on different seed storage methods for this species. 


\section{Acknowledgments}

This study has been funded by the Forest Research Center (Pest-OE/AGR/UI0239/ 2011). Technical support was provided by the project "Enerwood - Potential of native woody species for energy production from biomass" (PTDC/AGR-CFL/114826/2009) The authors would like to thank Regina Fabião for assisting in seed harvesting and Rita Moreira and Marta Carneiro for their help in seed shelling. We also thank an anonymous referee for helpful comments on the manuscript.

\section{References}

Barceló M, Parera J (2005). Jardinería e escasez de agua [Landscaping and water shortage]. Bricojardinería y Paisajismo 133: 24-27.

Benayas J, López-Pintor A, García C, Cámara N, Strasser R, Sal A (2002). Early establishment of planted Retama sphaerocarpa seedlings under different levels of light, water and weed competition. Plant Ecology 159: 201-209. - doi: 10.102 3/A:1015562623751

Bingre P, Aguiar C., Espírito-Santo D, Arsénio P, Monteiro-Henriques T (2007). Guia de campo as árvores e arbustos de Portugal continental [Field guide - trees and shrubs of continental Portugal]. Jornal Público, Fundação Luso-Americana para o Desenvolvimento, Liga para a Protecção da Natureza, Lisboa, Portugal, pp. 462.

Blondel J, Aronson J (1999). Biology and wildlife of the Mediterranean region. Oxford University Press, New York, USA, pp. 328.

Bonet A (2004). Secondary succession of semiarid Mediterranean old-fields in south-eastern Spain: insights for conservation and restoration of degraded lands. Journal of Arid Environments 56: 213-233. - doi: 10.1016/S0140-1963(03)000 $48-\mathrm{X}$

Caravaca F, Alguacil M, Figueroa D, Barea J, Roldán A (2003). Re-establishment of Retama sphaerocarpa as a target species for reclamation of soil physical and biological properties in a semi-arid Mediterranean area. Forest Ecology and Management 182: 49-58. - doi: 10.1016/S03 78-1127(03)00067-7

Castillo VM, Martinez-Mena M, Albaladejo J (1997). Runoff and soil loss response to vegetation removal in a semiarid environment. Soil Science Society of America Journal 61: 1116-1121. - doi: 10.2136/sssaj1997.036159950061000400 $18 \mathrm{x}$

Cortina J, Bellot J, Vilagrosa A, Caturla RN, Maestre FT, Rubio E, Ortíz de Urbina JM, Bonet A (2004). Restauración en semiarido [Restoration in semiarid environments]. In: "Avances en el Estudio de La Gestión del Monte Mediterráneo" (Vallejo VR, Alloza JA eds). Fundación Centro de Estudios Ambientales del Mediterráneo, Valencia, Spain, pp. 345-406. [in Spanish]

D’Agostino R, Belanger A, D'Agostino RJ (1990). A suggestion for using powerful and informative tests of normality. The American Statistician 44 (4): 316-321. - doi: 10.1080/00031
305.1990.10475751

DeCarlo LT (1997). On the meaning and use of kurtosis. Psychological Methods 2: 292-307. doi: 10.1037/1082-989X.2.3.292

Gibson MR, Richardson DM, Marchante E, Marchante H, Rodger JG, Stone GN, Byrne M, Fuentes-Ramiréz A, Georges N, Harris C, Johnson SD, Le Roux JJ, Miller JT, Murphy DJ, Pauw A, Prescott MN, Wandrag EM, Wilson JRU (2011). Reproductive biology of Australian acacias: important mediator of invasiveness? Diversity and Distributions 17: 911-933. - doi: 10.1111/j.1472-4642.2011.00808.x

Haase P, Pugnaire F, Fernández E, Puigdefábregas J, Clark S, Incoll L (1996). An investigation of rooting depth of the semiarid shrub Retama sphaerocarpa (L.) Boiss. by labeling of ground water with a chemical tracer. Journal of Hydrology 177: 23-31. - doi: 10.1016/0022-1694(95) 02794-7

Haase P, Pugnaire F, Clark S, Incoll L (2000). Dynamics of cohorts of cladodes and related effects on reproduction in the shrub Retama sphaerocarpa in semi-arid south-eastern Spain. Plant Ecology 146: 105-115. - doi: 10.1023/A:10098 17100422

Hartmann HT, Kester DE, Davies Jr. FT, Geneve RL (1997). Plant propagation: principles and practices $\left(6^{\text {th }}\right.$ edn $)$. Prentice Hall, New Jersey, USA, pp. 912.

ISTA (2003). International rules for seed testing. International Seed Testing Association, Bassersdorf, Switzerland. [online] URL: http://www.seedtest.org/

Lafortezza R, Sanesi G, Chen J (2013). Largescale effects of forest management in Mediterranean landscapes of Europe. iForest 6: 331-335. doi: 10.3832/ifor0960-006

Lopez Gonzalez G (2004). Guia de los árboles y arbustos de la península Ibérica y Baleares $\left(2^{\mathrm{a}}\right.$ Edición) [Guide to trees and shrubs of the Iberian Peninsula and Balearic Islands]. Ediciones Mundi-Prensa, Madrid, Spain, pp. 894. [in Spanish]

López J, Devesa JA, Ruiz T, Ortega-Olivencia A (1999). Seed germination in Genisteae (Fabaceae) from south-west Spain. Phyton 39: 107129. [online] URL: http://www.landesmuseum. at/pdf_frei_remote/PHY_39_1_0107-0129.pdf

MacDonald L, Larsen I (2009). Runoff and erosion from wildfires and roads: effects and mitigation. In: "Land Restoration to Combat Desertification: Innovative Approaches, Quality Control and Project Evaluation" (Bautista S, Aronson J, Vallejo V eds). Fundación Centro de Estudios Ambientales del Mediterráneo, Valencia, Spain, pp.145-167.

Manzano P, Malo JE, Peco B (2005). Sheep gut passage and survival of Mediterranean shrub seeds. Seed Science Research 15: 21-28. - doi: 10.1079/SSR2004192

Mondoni A, Tazzari ER, Zubani L, Orsenigo S, Rossi G (2013). Percussion as an effective seed treatment for herbaceous legumes (Fabaceae): implications for habitat restoration and agriculture. Seed Science and Technology 41: 175-187. [online] URL: http://www.ingentaconnect.com/ content/ista/sst/2013/00000041/00000002/art00 001

Moreno-Jiménez E, Vázquez S, Carpena-Ruiz RO, Esteban E, Peñalosa JM (2011). Using Mediterranean shrubs for the phytoremediation of a soil impacted by pyritic wastes in southern Spain: a field experiment. Journal of Environmental Management 92: 1584-1590. - doi: 10.1016/j.jenvman.2011.01.022

Pérez-Fernández MA, Rodríguez-Echeverría S (2003). Effect of smoke, charred wood, and nitrogenous compounds on seed germination of ten species from woodland in central-western Spain. Journal of Chemical Ecology 29 (1): 237-251. doi: 10.1023/A:1021997118146

Pérez-Fernández MA, Lamont BB, Marwick AL, Lamont WG (2000). Germination of seven exotic weeds and seven native species in south-western Australia under steady and fluctuating water supply. Acta Oecologica 21 (6): 323-336. - doi: 10.1016/S1146-609X(00)01084-5

Piotto B, Ciccarese L (1999). Storage of scarified seeds of shrubs and trees in the legume family. Canadian Tree Improvement Association News Bulletin 30: 6-7. [online] URL: https://www.for. gov.bc.ca/hti/publications/tswg/TSWGNewsbulletin30.pdf

Piotto B, Di Noi A (2003). Seed propagation of mediterranean trees and shrubs (Piotto B, Di Noi A eds). APAT - Agency for the Protection of the Environment and for Technical Services, Rome, Italy, pp. 108. [online] URL: http://www.isprambiente.gov.it/contentfiles/00003500/3512-manuali-2003-16.pdf/at_download/file

Prieto I, Kikvidze Z, Pugnaire F (2010). Hydraulic lift: soil processes and transpiration in the Mediterranean leguminous shrub Retama sphaerocarpa (L.) Boiss. Plant and Soil 329: 447-456. - doi: 10.1007/s11104-009-0170-3

Pugnaire FI, Lázaro R (2000). Seed bank and understorey species composition in a semi-arid environment: the effect of shrub age and rainfall. Annals of Botany 86: 807-813. - doi: 10.1006/ anbo. 2000.1240

Pugnaire FI, Luque MT, Armas C, Gutiérrez L (2006). Colonization processes in semi-arid Mediterranean old-fields. Journal of Arid Environments 65: 591-603. - doi: 10.1016/j.jaridenv. 2005.10.002

Radich MC, Alves AM (2000). Dois séculos da floresta em Portugal [Two centuries of forests in Portugal]. CELPA - Associação da Indústria Papeleira, Lisboa, Portugal, pp. 226.

Rivest D, Rolo V, López-Díaz L, Moreno G (2011). Shrub encroachment in Mediterranean silvopastoral systems: Retama sphaerocarpa and Cistus ladanifer induce contrasting effects on pasture and Quercus ilex production. Agriculture, Ecosystems and Environment 141: 447454. - doi: 10.1016/j.agee.2011.04.018

Robles AB, Castro J, González-Miras E, Ramos ME (2005). Effects of ruminal incubation and goats ingestion on seed germination of two legume shrubs: Adenocarpus decorticans Boiss. and Retama sphaerocarpa (L.) Boiss. In: "Sus- 
tainable Grazing, Nutritional Utilization and Quality of Sheep and Goat Product". Proceedings of the "First Joint Seminar of the FAOCIHEAM Sheep and Goat Nutrition and Mountain and Mediterranean Pasture Sub-Networks" (Alcaide EM, Ben Salem H, Biala K, MorandFehr $\mathrm{P}$ eds). CIHEAM/FAO/CSIC, Zaragoza, Spain, pp. 111-115.

Ruiz de la Torre J, Carreras C, García Viñas I, Orti M (1996). Manual de la flora para la restauración de áreas críticas y diversificación en masas forestales [Manual of the flora for restoration of critical areas and diversification in forest stands]. Junta de Andalucía - Consejería de Medio Ambiente, Sevilla, Spain, pp. 208. [in Spanish]

Ruiz-Peinado R, Moreno G, Juarez E, Montero G, Roig S (2013). The contribution of two common shrub species to aboveground and belowground carbon stock in Iberian dehesas. Journal of Arid Environments 91: 22-30. - doi: 10.1016/j.jarid env.2012.11.002

Ruxton GD, Beauchamp G (2008). Time for some a priori thinking about post hoc testing. Behavioral Ecology 19 (3): 690-693. - doi: 10.1093/beheco/arn020

Silva JBA (1969). Memória sobre a necessidade e utilidades do plantio de novos bosques em Portugal (2nd edn) [Memory on the necessity and utility of the planting of new forests in Portugal]. Academia das Ciências de Lisboa, Lisboa, Portugal, pp. 171. [in Portuguese]

Talavera S (1997). Retama Raf. In: "Flora Iberica 7(II)" (Talavera S, Aedo C, Castroviejo S, Herrero A, Romero C, Salgueiro FJ, Velayos M eds). Real Jardín Botánico, CSIC, Madrid, Spain, pp. 137-141. [online] URL: http://www.floraiberica. es/floraiberica/texto/pdfs/07_11\%20Retama.pdf
Thirgood JV (1981). Man and the Mediterranean forest: a history of resource depletion. Academic Press, New York, USA, pp. 194.

Vallejo V (2009). Problems and perspectives of dryland restoration. In: "Land Restoration to Combat Desertification: Innovative Approaches, Quality Control and Project Evaluation" (Bautista S, Aronson J, Vallejo V eds). Fundación Centro de Estudios Ambientales del Mediterráneo, Valencia, Spain, pp. 13-23.

Willan RL (1991). A guide to forest seed handling: with special reference to the tropics. FAO Forestry Paper 20/2, DANIDA Forest Seed Center and Food and Agriculture Organization of the United Nations, FAO, Rome, Italy. [online] URL: http://www.fao.org/docrep/006/ad232e/A D232E00.htm\#TOC 